\title{
Physiological Studies of Single Plant Cells
}

PHysiologists will welcome a summary ("Physiological Studies of Single Plant Cells", by W. J. V. Osterhout, Biological Reviews, vol. 6, pp. $369-411$ ) of the extensive literature on the algæ Valonia and Nitella by one who has been so intimately associated with this work. The bibliography is a formidable one comprising 227 citations. The data obtained by three types of experimental procedure, namely, (1) chemical analysis, (2) measurement of potential differences at various boundary surfaces by the use of single cells suitably arranged to procure the desired electrical circuit, (3) measurement of electrical resistance or capacitance, are discussed.

The review is itself so condensed that any further summary of it would be impracticable. The electrical experiments are interpreted as supporting the idea that the external cell surfaces are non-aqueous in nature, of high resistance, and permitting little dissociation of salts. The relative order of the mobilities of ions in protoplasm (unlike the case of collodion) does not resemble that obtained for salts in water, but rather that for certain non-aqueous solvents. In spite of the discussion and the literature cited there will still be, no doubt, those who find it difficult to conclude that some of the theories advanced materially clarify the vexed question of the accumulation of electrolytes by living cells. It is a question whether (for example, in the case of the accumulation of $\mathrm{KCl}$ ) the facts warrant the more complicated assumption that accumulation of $\mathrm{KCl}$ involves penetration of undissociated $\mathrm{KOH}$, the energy necessary being furnished by metabolism with the liberation of an organic acid HA which is then exchanged for $\mathrm{HCl}$ of the external solution (see p. 377), rather than the simple statement that $\mathrm{KCl}$ accumulates against a concentration gradient, the energy necessary being supplied by metabolism. In this connexion the comprehensive experiments of Hoagland and Davis receive but incidental citation.

It seems curious that, whilst in certain connexions stress is laid upon the importance of the energy released by the cell and that salt accumulation is not a physico-chemical equilibrium, the multiple partition theory of Irwin should receive such favourable discussion, whilst the mathematical treatment seems to evade such energy supply and to involve mainly operations based on equilibria. It is possible that some of the interpretations of accumulation which apply solely to electrolytes, and not at all to nonelectrolytes, may be premature, whilst the view that the cell has at its disposal a source of energy which may produce accumulation of both electrolytes and non-electrolytes seems to have been rather lightly dismissed, though it has figured somewhat prominently in other writings upon Nitella.

Many will reiterate one of the concluding remarks : "But mere complexity should not baffle the analy. tical resources of modern science if all the variables can be measured. The greatest difficulty is that in attempting measurements we may change variables or create new ones without being aware of it." The necessarily scanty attention paid to experimental technique in so brief a review covering so wide a field leaves one unable to say to what extent many of the experiments were affected by such uncontrolled variables. In particular, the effect of the often arbitrary technique adopted on two of the most important variables when dealing with respiring plant cells, namely, the oxygen and carbon dioxide concentrations in the environment, with its consequent effect on metabolism and any processes determined by metabolism, remains difficult for the reader to evaluate.

\section{Meteorology of the Persian Gulf and Mekran}

TNTIL after an international aerial route had been established along the Persian coast, meteorological information for this region was very scanty; the systematic study of its climate rested mainly upon a few observing stations, making observations once a day only, which had been established by the India Meteorological Department. A more elaborate organisation arose in 1927 , in response to the needs of aviation, which took the form of a chain of telegraphic reporting stations extending from Karachi to Bushire and observing at 4 A.M. and 2 P.M. G.M.T., that is to say, at about 8 A.M. and 6 P.M. local mean time.

The records obtained in this way allowed of the construction of synoptic weather charts on modern lines ; each station, moreover, kept a diary of phenomena occurring in disturbed weather. It is usually considered necessary to have records over a long period of years for any region before attempting to discuss its climate. To obtain reliable 'normal' values for the different climatic elements, this is a real necessity, but a careful perusal of Dr. Banerji's recent publication* suggests that he has done a useful service by presenting a preliminary study, which appears to give the salient climatic features of an interesting region, and connects these with meteorological events over a wide region extending to the Asiatic "centre of action' in the north and to the

* India: Meteorological Department. Meteorology of the Persian Gulf and Mekran. By Dr. B. N. Banerji. Pp. iii $+65+9$ plates. (Calcutta: Government of India Central Publication Branch, 1931.) 3 rupees; $5 s .3 d$.

$$
\text { No. } 3261 \text {, VoL. 129] }
$$

south-east trade-winds of the southern part of the Indian Ocean.

As would be expected from geographical considerations, the climate of Mekran and the Persian Gulf has many points of resemblance with the better known climates of north-west India. There is a winter regime and a summer regime, and the differences between the two greatly transcend those that must inevitably arise through seasonal variations in the amount of solar radiation and in the length of the day. The explanation obviously lies in the disturbance set up by the great seasonal change of pressure over Asia, and by the invasion of the Indian area in summer by diverted south-east trades from beyond the equator, that cause the Indian ' rains'.

In winter, the Asiatic area of high pressure tends to show an extension south-westwards to Persia, but the fine and dry weather that might result from this is interrupted by the eastward passage of depressions known to Indian meteorologists as " western depressions'. About eight of these occur on an average in a winter month. Dr. Banerji found, as a result of a careful analysis of his synoptic charts, that these are generally the remains of depressions that have passed out of the eastern Mediterranean, or secondary disturbances connected with them, such as are frequently found to occur when a depression crosses mountainous regions or is nearing the end of its life-history. Their behaviour and mode of formation are considered by him to conform with Norwegian views as to the origin of the depressions of temperate latitudes. 